\title{
Commentary
}

\section{Towards a smart biosafety regulation: The case of Kenya}

\author{
Ann KINGIRI ${ }^{1 *}$ and Seife AYELE ${ }^{2}$ \\ 1 Innogen ESRC Centre, Development Policy and Practice, Technology Faculty, The Open University, Walton Hall, MK7 6AA, UK \\ 2 International Livestock Research Institute (ILRI), P.O. Box 30709-00100, Nairobi, Kenya
}

\begin{abstract}
It is emerging that benefits of new innovations in agricultural biotechnology may not be realised without appropriate biosafety regulatory mechanisms. The Kenyan regulatory experiences related to regulation of genetically engineered $(\mathrm{GE})^{\star \star}$ agricultural activities are explored to provide some basis for defining the challenges involved in biosafety regulation. The various shortcomings in the way the Kenyan biosafety process has been implemented are consistent with the way regulatory systems have been evolving in Africa. The proposed adoption of a "smart regulation" provides the basis for a learning process through which subsequent biotechnology policy initiatives can be improved.
\end{abstract}

Keywords: agricultural biotechnology / biosafety / smart regulation / Kenya

\section{INTRODUCTION}

There are significant innovation issues in life sciences such as GE agricultural innovations that have demanded appropriate governance and regulation (Lyall and Tait, 2005). This being the case, regulation in life sciences is becoming widely adopted as a norm globally and transnationally. Consequently, different regulation styles originating from North America or Europe have emerged, based on whether it is "process of science" or "products of science" (Tait and Levidow, 1992). These regulatory styles have unquestionably impacted regulatory trajectories adopted in other continents that are catching up in terms of innovation as well as implementation of regulatory systems (Scoones, 2002). This article proposes the adoption of a "smart regulation" approach which might contribute to an innovative way of conceptualising life science innovations. To achieve this we explore the Kenyan regulatory experiences related to regulation of genetic engineering agricultural activities to

* Corresponding author: annakingiri@yahoo.com

** The technologies referred to here are products of manipulations of living organisms but we make distinction between traditional and modern biotechnologies. The traditional approach allows the development of new products (such as seed varieties) by the process of selection from genetic material already present within a species, while the modern (transgenic) approach or genetic engineering (GE) develops products (such as seed varieties) through insertion of genetic material from different species into a host plant. provide some basis for locating the challenges involved in biosafety regulation ${ }^{1}$. This reveals various shortcomings in the way the Kenyan biosafety process has been implemented, consistent with the way regulatory systems have been evolving in Africa. We suggest that these challenges should be perceived as a requisite learning process through which subsequent biotechnology policy initiatives could be improved.

\section{CURRENT STATUS OF BIOSAFETY REGULATION IN KENYA}

Agriculture plays a key role in Kenya's economy and the livelihoods of its people. In 2005 it accounted directly for 25,80 and $60 \%$ of gross domestic product; employment; and export earnings respectively (RoK, 2005a). It is earmarked as an important sector in meeting Kenya's regional and global commitments such as the Millennium Development Goals (RoK, 2005b), as well as local policies and strategies initiated by the government to address hunger and poverty, and transform science and technologies into innovative ventures (KARI, 2005; RoK, 2005a).

In recognition of the importance of agriculture, Kenya has been very active in advancing biotechnology research and development and has currently approved

\footnotetext{
${ }^{1}$ Biosafety is the avoidance of risk to human health and safety, and the conservation of the environment as a result of the use of GE products (RoK, 2009).
} 
transgenic crop biotechnology trials on cassava, sweet potato, cotton, maize and sorghum (Tab. 1). With respect to biosafety, Kenya is a signatory to the Convention on Biological Diversity (CBD) and has ratified the Cartagena Protocol on Biosafety (CPB), obligating the development of a biosafety legislative framework (Biotechnology Policy, Biosafety Act and implementing regulations). Consequently, a regulatory regime for biosafety that commenced with development of the "Regulations and guidelines for Biosafety in Biotechnology" (RoK, 1998) was proposed as a system to manage applications for testing crop biotechnology activities. These regulations provide minimum standards for inspection and monitoring which are commensurate with the levels of risk under consideration (RoK, 1998). The regulations have been interim (Harsh, 2005; Traynor and Macharia, 2003; Wakhungu and Wafula, 2004) but have provided an environment for establishing an institutional framework for biosafety implementation. Subsequent efforts toward biosafety regulation implementation from the United Nations Environment Programme-Global Environment Facility (UNEP-GEF) resulted in the National Biotechnology Policy (RoK, 2006), and the Biosafety Act (RoK, 2009).

Various government agencies are involved in the implementation of the biosafety regulations (Harsh, 2005; Odame et al., 2003a, 2003b; Traynor and Macharia, 2003). These include the Kenya Plant Health Inspectorate Service (KEPHIS) and National Environmental Management Authority (NEMA). As a consequence, biotechnology research and development activities are subject to other national regulatory instruments that are commensurate with the regulatory mandates of these agencies. For instance the Plant Protection Act (Cap 324) enforced by KEPHIS provides for the regulation of all plants and plant products against introduction into Kenya of injurious pests and diseases.

Such a gap between policy and institutional development on the one hand, and research and development on the other, has been a feature of biotechnology development in Kenya. We argue that policies and, in particular, effective biosafety policies, play a crucial role in supporting the process of innovative research and development.

\section{AN APPROACH TO SMART BIOSAFETY REGULATION}

The growing scholarship on sociological studies in science, technology and innovation policies, science policy and knowledge production dynamics has rich theoretical concepts that provide insights to enhance the understanding of an appropriate regulatory practice towards a "smart regulation". For instance, the innovation systems perspective provides a framework that befits the complexity of life sciences and the contextual multiple factors that frame its debate ( $c f$. Jasanoff, 1987; Newell, 2002; Scoones, 2002). Key to the innovation systems framework are actors and their roles, actors' attitudes and practices, the effects and characteristics of patterns on interventions, and the enabling framework for innovation (Hall, 2005; World Bank, 2007). While acknowledging the centrality of the other elements of the framework, we are mostly interested with the enabling environment - the key element of which is mainly the governance and regulation of life sciences, particularly agricultural biotechnology innovations.

We have used empirical evidence to track down the evolution of the biosafety regulatory process in Kenya following the informal governance of agriculture biotechnology (Harsh, 2005). This empirical evidence comes from data/reports generated as part of two ERSC funded projects $^{2}$, interviews, and relevant documents analysis. Empirical analysis of the biosafety regulatory policy process based on the accounts of scientists as practitioners and implementers of biosafety regulations informs the systemic understanding of the biotechnology innovation in Kenya. Consequently, the generated knowledge can contribute toward a smart biosafety regulatory process.

The evidence generated was triangulated with accounts of different players in Kenyan biotechnology debate and different sources. Triangulation tests the validity and authenticity of the findings and gives the analysis rigor, especially when diverse sources of knowledge are valuable in a knowledge intensive technology like biotechnology. Finally the data were subjected to thematic qualitative analytical tools that are loosely linked to grounded theory. This enables the analysis to be grounded in the perspectives of those who have been involved in the regulatory process, rather than the view of qualitative researchers.

\section{GENETIC ENGINEERING SCIENCE VERSUS BIOSAFETY REGULATORY SYSTEMS EVOLUTION: EMPIRICAL EXPLORATION}

Research trials on GE organisms in Kenya are currently being undertaken under public/private partnerships between the public research institutes, mainly the Kenya Agricultural Research Institute (KARI), and private collaborators (Tab. 1). Consequently, biotechnology in Kenya attracts a wide range of stakeholders that include scientist, donors, industry, farmers, policy makers, government agencies, pro and anti-GE non-governmental organisations (NGOs), and consumers.

${ }^{2}$ UK Economic and Social Research Council (ESRC) Science in Society Programme. 
Table 1. GE technological innovations in Kenya (adapted from Ayele et al., 2006 and secondary sources).

These trials have provided a practical testing environment for the implementation process of the biosafety regulatory systems in Kenya. Analytically, they reveal a complex interface between GE technology and biosafety policy process.

\begin{tabular}{|c|c|c|c|}
\hline GE activity & $\begin{array}{l}\text { Initiative trigger/Production } \\
\text { constraint }\end{array}$ & Stage of development & Collaborators/Partners \\
\hline $\begin{array}{l}\text { Sweet potato engineered } \\
\text { for disease resistance } \\
\text { (feathery mottle virus) }\end{array}$ & $\begin{array}{l}\text { The virus coat protein gene } \\
\text { availability from Monsanto } \\
\text { a Diseases attack causing low } \\
\text { yields }\end{array}$ & $\begin{array}{l}\text { Contained laboratory and con- } \\
\text { fined field trials }\end{array}$ & $\begin{array}{l}\text { KARI, Monsanto, ABSPa, } \\
\text { ISAAA }^{\text {b }} \text {, Michigan State Uni- } \\
\text { versity, Kenyan universities }\end{array}$ \\
\hline $\begin{array}{l}\mathrm{Bt} \text { maize-IRMA }{ }^{\mathrm{c}} \text { project } \\
\text { engineered for resistance } \\
\text { to insects (African maize } \\
\text { stem borer) }\end{array}$ & $\begin{array}{l}\text { a } B t \text { technology availability } \\
\text { from Syngenta } \\
\text { a Pests infestation in particular } \\
\text { maize stalk borer }\end{array}$ & $\begin{array}{l}\text { Contained laboratory and } \\
\text { greenhouse and confined field } \\
\text { trial }\end{array}$ & $\begin{array}{l}\text { KARI, CIMMYT }{ }^{\mathrm{d}} \text {, Syngenta, } \\
\text { Rockefeller Foundation, } \\
\text { United State Agency for } \\
\text { International Development } \\
\text { (USAID), Kenyan universities }\end{array}$ \\
\hline $\begin{array}{l}\text { Cassava engineered for } \\
\text { Cassava Mosaic Disease } \\
\text { (CMD) resistance-African } \\
\text { Cassava Mosaic Virus } \\
\text { and East African Cassava } \\
\text { Mosaic Virus }\end{array}$ & $\begin{array}{l}\text { The coat protein gene avail- } \\
\text { ability from Monsanto } \\
\text { a Disease infestation in partic- } \\
\text { ular the CMD significantly re- } \\
\text { ducing yields }\end{array}$ & $\begin{array}{l}\text { Contained laboratory and } \\
\text { greenhouse application has } \\
\text { been pending for confined } \\
\text { field trials }\end{array}$ & $\begin{array}{l}\text { KARI, Danforth Center-USA, } \\
\text { USAID, Cornell University, } \\
\text { ISAAA, Kenyan universities }\end{array}$ \\
\hline $\begin{array}{l}\text { Bt cotton engineered for } \\
\text { insect resistance-cotton } \\
\text { bollworm }\end{array}$ & $\begin{array}{l}\text { a } B t \text { technology availability } \\
\text { from Monsanto } \\
\text { a Declining production perfor- } \\
\text { mance - pest infestation, in } \\
\text { particular African bollworm }\end{array}$ & $\begin{array}{l}\text { Contained greenhouse and } \\
\text { confined field trials }\end{array}$ & $\begin{array}{l}\text { KARI, Delta-Pine South } \\
\text { Africa, Monsanto, Kenya } \\
\text { Industrial Research Develop- } \\
\text { ment Institute (KIRDI) }\end{array}$ \\
\hline $\begin{array}{l}\text { Transgenic sorghum for } \\
\text { resistance to striga } \\
\text { parasitic weed }\end{array}$ & $\begin{array}{l}\text { Availability of a collabora- } \\
\text { tive research grant } \\
\text { a The persistence of parasitic } \\
\text { striga weed in cereals growing } \\
\text { areas in Kenya }\end{array}$ & $\begin{array}{l}\text { Contained laboratory and } \\
\text { screen house proof of concept } \mathrm{t}^{\mathrm{e}}\end{array}$ & $\begin{array}{l}\text { Kenyatta University (Kenya), } \\
\text { University of California, } \\
\text { Davis (USA) }\end{array}$ \\
\hline
\end{tabular}

a Agricultural Biotechnology Support Programme.

${ }^{\mathrm{b}}$ International Service for Acquisition of Agric-Biotech Applications.

${ }^{\mathrm{c}}$ Insect Resistant Maize for Africa.

${ }^{\mathrm{d}}$ International Maize and Wheat Improvement Centre.

e This project is for proof of the concept as part of a Ph.D. student research work and has no immediate plans for commercialisation.

Over the past two decades Kenyan crop agricultural biotechnology has shown some major changes:

- The GE initiative commenced in 1991 with sweet potato and developed four other initiatives by 2008 : cassava, cotton, maize and sorghum (Tab. 1).

- Largely due to the biotechnology initiatives, the capacity to harness biotechnology and biosafety has increased over the last 20 years. As a result internal and external learning opportunities were created for scientists in both research institutes and policy and regulatory arenas. KARI, the main research institution undertaking most of the biotechnology initiatives, has recognised the importance of biotechnology as evidenced by the increased institutional expenditure in such activities (KARI, 2005).
The government has also endeavoured to increase its budgetary provision for research and development, including biotechnology (RoK, 1982, 2005a).

- Biotechnology activities have spurred the development and transformation of the institutions and organisations to support this technology transfer (Tab. 2).

The early GE research initiatives in 1990's triggered the development of the 1998 regulations and guidelines (RoK, 1998). However, the National Biotechnology Development Policy of 2006 (RoK, 2006) was the first attempt by the government to charter a roadmap for biotechnology development in Kenya. It paved the way for the development of a legal framework to govern products of modern biotechnology. The policy set the scene for the formation of an administrative and 
Table 2. Technological and institutional innovations and biosafety policy milestones in Kenyan GE trials (adapted from Harsh (2005) after updating and review).

\begin{tabular}{|c|c|}
\hline Period & Activity \\
\hline 1991 & Commencement of sweet potato field trial \\
\hline 1997 & $\begin{array}{l}\text { KARI-Institutional Biosafety Committee (IBC) formed; Kenya Plant Health Inspectorate Service } \\
\text { (KEPHIS) was established through a government Legal Notice }\end{array}$ \\
\hline 1998 & $\begin{array}{l}\text { Regulations and guidelines for biosafety in biotechnology adopted; establishment of National Biosafety } \\
\text { Committee (NBC); approval of 1st transgenic field trial (sweet potato) }\end{array}$ \\
\hline 1999 & $\begin{array}{l}\text { a Commencement of IRMA phase } 1 \text { project } \\
\text { a Establishment of Biosafety framework through UNEP-GEF support }\end{array}$ \\
\hline 2002-2006 & $\begin{array}{l}\text { Various training programmes took place, for example, training of policy makers, IBCs and NBC members } \\
\text { on handling GE trials applications under UNEP-GEF program }\end{array}$ \\
\hline 2000 & $\begin{array}{l}\text { a Importation of GE sweet potato from US by KARI for field trials } \\
\text { a Kenya signs the Cartagena Protocol, and ratifies the Cartagena Protocol in } 2003\end{array}$ \\
\hline 2001 & Contained laboratory approval to conduct $B t$ maize trial using transgenic $B t$ leaves \\
\hline 2003 & $\begin{array}{l}\text { a Confined greenhouse approval to conduct } B t \text { maize trial using } B t \text { seed; } B t \text { cotton approved for screen } \\
\text { house trials; transgenic cassava approved for screen house trials } \\
\text { a Reviewed regulations and guidelines for biosafety in biotechnology; biotechnology policy drafted; } \\
\text { biosafety bill drafted }\end{array}$ \\
\hline 2004 & $\begin{array}{l}\text { Transgenic sweet potato failure to confer resistance to sweet potato feathery mottle virus becomes pub- } \\
\text { licly known } \\
\text { at maize approved for open field trials (Open quarantine/FTs) } \\
\text { Approval of } B t \text { cotton open field trials }\end{array}$ \\
\hline 2005 & $\begin{array}{l}\text { Approval and planting of } B t \text { maize open field trial; importation of } B t \text { cotton seeds and planting of } B t \text { cot- } \\
\text { ton open field trials } \\
\text { a } B t \text { maize open field trial publicly halted; re-approval of the } B t \text { maize open field trial with reviewed and } \\
\text { stricter biosafety requirements; open field trial cassava application denied approval by NBC }\end{array}$ \\
\hline 2006 & Adoption of botechnology policy and approval of biosafety bill \\
\hline 2007 & $\begin{array}{l}\text { a } B t \text { cotton open field trial used by proponents of GE technology and scientists to lobby for political } \\
\text { support; approval of second } B t \text { cotton trial } \\
\text { a First and second mentioning of the biosafety bill in parliament } \\
\text { a Parliament prologues to pave way for general elections } \\
\text { a Intensive engagement of Non-Governmental Organizations-NGOs media (for and against GE technology } \\
\text { and enactment of the biosafety bill) }\end{array}$ \\
\hline 2008 & Draft Biosafety Bill 2008 published and approved \\
\hline 2009 & Biosafety Act, 2009 passed and gazetted as a Law \\
\hline
\end{tabular}

legal framework for biotechnology development and use. Therefore, the Biosafety Act, 2009 and regulations are intended to provide a legal stance to the biotechnology activities, as well as set the base for implementation of the Cartagena Protocol.

Despite these developments, most respondents still consider that innovation in agricultural biotechnology suffers from some major drawbacks. This is attributed largely to the slow implementation of Cartagena Protocol through the enactment of an effective biosafety regulatory regime and to the following challenges: (i) Inadequate and unbalanced institutional and technical capacity: Kenya has about ten public universities that are yet to engage in GE basic research. However, most of the GE activities have been within KARI, a public research institute. Only recently has Kenyatta University; an academic and research institution, obtained a regulatory approval to undertake transgenic work. Analysis of interview data suggests that the regulatory capacities are inadequate to effectively and sustainably monitor and inspect research and products of biotechnology activities. It also suggests the limited potential for biotechnology innovation transfer and sustainability. For example, 
the desire by academic institutions to join in the biotechnology trials implementation process implies changing academic curricula (which is already happening). These universities have also formed institutional biosafety committees to assist scientists in putting up viable biotechnology research proposals that address biosafety risks. Despite this, the respondents from academic institutions reiterated the difficulty to translate academic initiatives from basic knowledge transfer to economic gains (where other users can benefit) and attribute this to the high investments needed in GE science.

(ii) Unsustainable funding for research and regulatory process: Government spending on research and development in general has continually declined (Bananuka, 2007; KARI, 2005), and this has partly contributed to the public/private partnerships characteristic of biotechnology initiatives in Kenya. In addition, initiatives to develop a biosafety regulatory regime have largely been donor driven (e.g. UNEP-GEF; USAIDProgram for Biosafety Systems). This donor dependence attitude is often criticized since it is not sustainable and the government has been urged to increase its budgetary funding of research and development, as well take up an active role in the development of sustainable biosafety regulatory policies.

(iii) Contestations and lack of consensus on policy and strategy: The initial objective of the on-going biotechnology trials was to provide proof-of-concept in anticipation of paving the way for commercialization of biotechnology products in Kenya. More recently, with open field trials, the popularization of the concept "seeing is believing" has emerged. This implies that policy makers and the public can be persuaded to take up a technology that is "real and demonstrable", thereby raising awareness and reducing fear associated with the negative perception of GMOs (Ayele, 2007). This "tangible" evidence of GE potential in the form of "field trials" has been used by biotechnology proponents, who include scientists and policy makers, to push for the Biosafety Act that many respondents consider is the key for advancing adoption of biotechnology. They believe that this will unlock the GE potential for the farmers to reap the benefits. However, it is noteworthy that, despite the research activities and policies initiatives, no GE products have reached farmers to date. This has been attributed to many factors, but proponents argue that lack of a legal biosafety policy framework, to guide the technology transfer process, is to blame for the delay.

It is evident that the implementation of the Kenyan biosafety regulatory process has been hampered by several challenges that include institutional and regulatory capacities as well as governance and representation challenges.

\section{TOWARDS A SMART BIOSAFETY REGULATION}

Various factors contribute to the type of regulations adopted by respective countries. This is clearly evident from key points of the Kenyan case:

First, governance of life sciences is very complex because divergence of views are linked to uncertainty and perceptions of risk, as well as the global nature of the issues (Levidow et al., 2005; Scoones, 2002). On the other hand, there are those who are convinced that this science is a significant innovative endeavour for solving many of world food and resource challenges ( $c f$. FAO, 2004; Hisano, 2005).

Second, respective governments have been placed in an awkward position whereby they have been forced to adopt a dual role (promotional and regulatory). On the one hand they have been seen to push for GE technology as a developmental tool, while on the other they have pushed for biosafety regulations to address the scepticism held by the public regarding potential dangers of life sciences to health and environment.

Third, unlike other science and technology areas, life sciences are mainly mode 2 sciences ${ }^{3}$ demanding new ways of doing science due to the increased transdisciplinarity, multi-functionality and high integration (Gibbons et al., 1994; Nowotny et al., 2001; Russell et al., 2008).

Clearly, the nature of biotechnology innovations and lack of consensus on policy strategies, particularly biosafety policies, are highly contested. This is because the formulation of biosafety regulatory policies (or safety standards for application of biotechnology) and implementation has been perceived to be "everyone's business" by stakeholders (Juma and Serageldin, 2007). In addition, regulation has been seen as the only way to manage these controversies (Braithwaite et al., 2007; Newell, 2002; Scoones, 2002). In view of this, Tait et al. (2007) provide insights on how a "smart regulation" may be enhanced. They note that lessons learnt with regards to regulatory influences on innovation systems should be perceived as opportunities to review or develop appropriate future regulatory systems. This is because regulatory systems have a major impact on various aspects related to innovation capacity; for instance, research and development trends, partnerships, and intellectual property exploitation. From this concept of learning, Africa for example, may gain from the successes, failures and consequences of the regulatory systems elsewhere e.g. Europe and USA. With regards to Kenya, experiences

\footnotetext{
${ }^{3}$ In simple terms, mode 2 refers to "a changed way of doing science in which knowledge is produced in a more contextualized way in the context of application" (Gibbons et al., 1994).
} 
gained from biosafety regulation implementation over the last decade may inform further policy initiatives.

Tait et al. (2007) further note that regulatory policies may impact on scientific practice and recommend that socially responsive policies encouraging reflexivity on the part of firms and individuals are bound to be more effective to spur economic changes as opposed to constraining regulatory policies. Other scholars have offered insights into how regulations can be reconceptualized in order to enhance development. In particular, scholars who have focused on developing countries, generally argue that understanding the local context would influence the way regulations are implemented towards guiding development of products of science ( $c f$. Newell, 2002; van Zwanenberg et al., 2008). Others (Nowotny et al., 2001, pp. 96-120) have recommended re-conceptualization of scientific practice, with emphasis on institutional and individual "reflexivity" towards "integration." This addresses the interconnection between the new sciences and scientists ${ }^{4}$, as well as society and societal demands such as ethical and biosafety considerations.

According to Black (1998), regulation has an important role to play in connecting the arguments of participants in facilitating the integration of the wide range of views as to the appropriate course that the technology and its regulation should take. She proposes a "facilitative approach" to regulation where the concepts of negotiation and integration are encouraged as opposed to the current "control approach". Further, from the innovation systems perspective, recognition of the role of different actors in the innovation chain enhances understanding of the process of innovation in line with the different components and identifying the systemic failures that affect innovations (World Bank, 2007). From innovation systems thinking, scientific and policy aspects are tackled holistically. Consequently, usable knowledge (Haas, 2004) is created in the context of practice (Gibbons et al., 1994; Nowotny et al., 2001, 2003).

\section{CONCLUSIONS}

The delivery mechanisms for Kenyan biotechnology innovation to potential recipients and the analogous institutional arrangements are perceived to be weak. In addition, strategies to support sustainable endeavours towards pro-poor technologies are also currently weak or non-existent. These weaknesses need to be addressed for

\footnotetext{
${ }^{4}$ For instance the environment under which molecular science takes place, including the practitioner scientists may be perceived to be highly confined, removed from the real societal environment (Knorr-Cetina, 1995).
}

any meaningful gain from biotechnology to be realised. In conclusion, we recommend:

- Representation of diverse and relevant voices in the biosafety policy process;

- Kenya must develop home-grown biotechnology and biosafety capacity in order to instil "ownership" of thinking into the minds of scientists and policy makers, thereby enhancing public trust;

- The Kenyan regulatory policy development process should take advantage of integrating the political and social "blind spots" assumed or taken for granted in the "ad-hoc" policy implementation process. A hypothetical consensus-building system oriented approach is recommended if benefits from life sciences are to become sustainable.

\section{ACKNOWLEDGEMENTS}

This paper is based on research conducted in Kenya over the period 2003-2008 (a) funded by the UK Economic and Social Research Council (ESRC) Science in Society Programme (Award Reference Nos: RES-151-25-0002 and RES- 160-25-006); and (b) doctoral research programme funded by The Open University, UK. The authors gratefully acknowledge this support. The views expressed in the paper are the authors and do not necessarily reflect those of the ESRC or the Open University.

Received January 27, 2009; accepted July 30, 2009.

\section{REFERENCES}

Ayele S (2007) IRMA: a science and technology-based intervention to reduce hunger? Case study course teaching material, TU870, Capacities for Managing Development, The Open University, Milton Keynes, UK

Ayele S, Chataway J, Wield D (2006) Partnerships in African Crop Biotech. Nat. Biotechnol. 24: 619-621

Bananuka JA (2007) Biotechnology capacity building needs in Eastern Africa. In Biotechnology, Eastern African Perspectives on Sustainable Development and Trade Policy, International Centre for Trade and Sustainable Development (ICTSD), Geneva, Switzerland and African Technology Policy Studies (ATPS) network, Nairobi, Kenya, pp 29-43

Black J (1998) Regulation as facilitation: negotiating the genetic revolution. The Modern Law Review 61: 621-660

Braithwaite J, Coglianese C, Levi-Faur D (2007) Can regulation and governance make a difference? Regulation $\mathcal{E}$ Governance 1: 1-7

FAO (2004) The State of Food \& Agriculture. Agricultural biotechnology: meeting the needs of the poor?, Food \& Agricultural Organisation (FAO), Rome, Italy 
Gibbons M, Limoges C, Nowotny H, Schwartzman S, Scott P, Trow M (1994) The new production of knowledge: the dynamics of science and research in contemporary societies. London, Sage

Haas PM (2004) When does power listen to truth? A constructivist approach to the policy process. J. Eur. Public Policy 11: 569-592

Hall A (2005) Capacity development for agricultural biotechnology in developing countries: An innovation systems view of what is and how to develop it. J. Int. Dev. 17: 611-630

Harsh M (2005) Formal and informal governance of agricultural biotechnology in Kenya: Participation and accountability in controversy surrounding the draft biosafety bill. J. Int. Dev. 17: 661-677

Hisano S (2005) A critical observation on the mainstream discourse of biotechnology for the poor. Tailoring Biotechnologies 1: 81-106

Jasanoff S (1987) Contested boundaries in policy-relevant science. Soc. Stud. Sci. 17: 195-230

Juma C, Serageldin I (Lead Authors) (2007) Freedom to Innovate: Biotechnology in Africa's Development, A report of the High-Level African Panel on Modern Biotechnology. African Union (AU) and New Partnership for Africa's Development (NEPAD), Addis Ababa and Pretoria

Kenyan Agricultural Research Institute (KARI) (2005) KARI Strategic Plan, 2005-2015, Ministry of Agriculture

Knorr-Cetina K (1995) Laboratory studies: the cultural approach to the study of science. In Jasanoff S, Markle GE, Petersen JC, Pinch T, Handbook of Science and Technology Studies, Sage, London, pp 140-166

Levidow L, Carr S, Wield D (2005) European Union regulation of agric-biotechnology: precautionary links between science, expertise and policy. Sci. Public Pol. 32: 261-276

Lyall C, Tait J (2005) A new mode of governance for science, technology, risk and the environment? In Lyall C, Tait J, eds, New modes of governance. Developing an integrated policy approach to science, technology, risk and the environment, Aldershot, Ashgate, pp 177-188

Newell P (2002) Biotechnology and politics of regulation. IDS Working Paper 146, Biotechnology Policy Series 3, University of Sussex, Brighton, UK

Nowotny H, Scott P, Gibbons M (2001) Re-thinking science: knowledge and the public in an age of uncertainty. Polity press, Cambridge, UK

Nowotny H, Scott P, Gibbons M (2003) 'Mode 2' revisited: the new production of knowledge. Minerva 41: 179-194

Odame H, Kameri-Mbote P, Wafula D (2003a) Governing modern agricultural biotechnology in Kenya: implications for food security. IDS Working Paper 199, University of Sussex, Brighton, UK
Odame H, Kameri-Mbote P, Wafula D (2003b) Innovation and policy process: the case of transgenic sweet potato in Kenya. African Centre for Technology Studies (ACTS) press, Nairobi, Kenya

Republic of Kenya (RoK) (1982) Sessional paper No. 5 on the acceptance of the Report of the National Council for Science and Technology (NCST); entitled "Science and Technology for Development"

RoK (1998) Regulations and Guidelines for Biosafety in Biotechnology for Kenya, National Council for Science and Technology (NCST), No. 41

RoK (2005a) Strategy for Revitalizing Agriculture (SRA), 2004-2014. Ministry of Agriculture, Ministry of Livestock \& Fisheries Development, and Ministry of Cooperative Development \& Marketing

RoK (2005b) Millennium Development Goals in Kenya: needs and costs. http://www.ke.undp.org/ KenyaMDGNeedsAssessment.pdf [accessed July 9 2007]

RoK (2006) National Biotechnology Development Policy (2006). Government printer, Nairobi, Kenya

RoK (2009) The Biosafety Act, 2009, Special Kenya Gazette Supplement Feb. 2009, Government printer, Nairobi, Kenya

Russell WA, Wickson F, Carew AL (2008) Transdisciplinarity: context, contradictions and capacity. Futures 40: 460-472

Scoones I (2002) Science, policy and regulation: challenges for agricultural biotechnology in developing countries. IDS Working Paper 147, University of Sussex, Brighton, UK

Tait J, Levidow L (1992) Proactive and reactive approaches to risk regulation: the case of biotechnology. Futures 24: 219-231

Tait J, Chataway J, Wield D (2007) Appropriate governance of life sciences. The case for smart regulation. Innogen Policy Brief. No. 2, available at http://www.innogen.ac.uk

Traynor P, Macharia H (2003) Analysis of the biosafety system for biotechnology in Kenya: application of a conceptual framework. International Service for National Agricultural Research (ISNAR), Country Report 65, The Hague, The Netherlands

van Zwanenberg P, Ely A, Smith A (2008) Rethinking regulation: international harmonisation and local realities. STEPS Working Paper 12, Brighton, STEPS Centre, UK

Wakhungu J, Wafula D (2004) Introducing Bt cotton. Policy lessons for smallholder farmers in Kenya. African Centre for Technology Studies (ACTS) press, Nairobi, Kenya

World Bank (2007) Enhancing agricultural innovation: How to go beyond the strengthening of research systems. The World Bank, Washington, DC. www.worldbank.org/rural 